\title{
101 uses for a life sciences PhD
}

Sir - The underlying assumption of the report by the US National Research Council on $\mathrm{PhDs}$ in the life sciences is that leaving academic science is a disaster (Nature 395, 103; 1998).

You say "the report dismisses the notion that $\mathrm{PhD}$ programmes should be broadened to prepare graduates for alternative careers that, it maintains, do not require a $\mathrm{PhD}$ ". This assumption that a life science $\mathrm{PhD}$ is only useful training for scientific research is narrow-minded and not dynamic. For many years it was said that manufacturing did not require a university degree. However, with many new university graduates seeking jobs in the 1980s, manufacturing was restructured to incorporate modern technology and now employs many university graduates. Thus, an apparent glut of overtrained people increases productivity as their talents are transferred to new areas of employment.

We agree that providing better information to prospective students is an excellent idea. Applicants should know what jobs are available and what career paths exist both within and outside science. Then they should choose freely whether to begin their doctoral training. Setting an arbitrary quota on the number of PhDs allowed in the United States would be foolish. Economic history contains a wealth of examples of the failure of quota systems to perform efficiently. Young life scientists need improved information about career options, not limits on the number of PhDs.

Those who only want to clone themselves in economics departments are also lamenting that there are not enough jobs for PhDs at research universities. But economics $\mathrm{PhDs}$ who go into consulting and investment banking do very well and they bring a willingness to entertain complex solutions and creative insights.

Life science PhDs have similar opportunities to use their skills in marketing, sales, management, and research in the biotechnology and pharmaceutical industries. Their technical training is also of use as biotech equity analysts, patent attorneys and venture capitalists. Who is to say we aren't improving the lives of the individuals and increasing productivity? Andrew A. Bogan

Graduate Group in Biophysics,

University of California, San Francisco,

California 94143, USA

Elizabeth C. Bogan

Department of Economics, Princeton University, Princeton, New Jersey 08544, USA

\section{The Western front}

Sir - As Native American university faculty members, we are concerned about a major error concerning Native American history in Adam Kuper's review of Mark Cocker's book Rivers of Blood, Rivers of Gold (Nature 393, 533; 1998). Kuper's reference to the so-called Apache being "virtually bandit groups, established in the interstices between the British colonies and Mexico," is both insulting and ignorant. Recent scholarship makes it clear that the Apaches were essentially agriculturalists, and their so-called raids were attempts to protect their homelands from invasion.

Although Kuper complains about Cocker's reversal of the old Victorian bias, it seems he has nothing better to offer than a return to even older stereotypes of bandit tribes and small nomadic bands. The historical reality was much more complex, and some emphasis should be made of the strong links between indigenous peoples and the places from which they come. Understanding this relationship defines the tragedies that Cocker describes.

\section{Daniel Wildcat}

\section{Raymond Pierotti}

Haskell Indian Nations University,

Lawrence, Kansas 66046, USA

Kuper replies - We are dealing here with very broad-brush characterizations, and the label 'Apache' covers a variety of preconquest lifestyles. However, it is generally agreed that farming was a minor aspect of pre-conquest Apache subsistence activities, and that raiding was very significant, particularly among the Western Apache.
According to Encyclopedia Britannica, the Chiricahua (Geronimo's division) “were perhaps the most nomadic and aggressive of the Apache west of the Rio Grande". It was their nomadism that "made their predatory life-style possible". It is true, nevertheless, that the equally aggressive settlers forced a number of Apache groups into heroic acts of self-defence which were wrongly represented as unjustified raids.

\section{Adam Kuper}

Department of Human Sciences,

Brunel University,

Uxbridge,

Middlesex UB8 3PH, UK

\section{Coelacanth populations}

\section{may go with the flow}

Sir - The coelacanth population recently discovered in the Sulawesi Sea, north of Sulawesi, Indonesia ${ }^{1,2}$, may very well be related to those found earlier near the Comoran Islands in the western Indian Ocean. The ocean circulation map shown ${ }^{2}$ is in error: there is indeed an oceanographic connection between Sulawesi and the Comoran Islands region.

Oceanographic studies ${ }^{3-5}$ show that there is a direct flow of surface and thermocline (upper $400 \mathrm{~m}$ ) water from the Mindanao Current of the North Pacific into the Sulawesi Sea. After traversing Makassar Strait this flow, called the Indonesian throughflow, enters the Flores and Banda Seas before spreading into the Timor Sea and Indian Ocean. Once in the Indian Ocean the Indonesian water spreads westward as a low salinity feature embedded within the South Equatorial Current along $12^{\circ} \mathrm{S}$, eventually reaching the vicinity of the Comoran Islands. I suggest that coelacanth populations may exist along the route of this flow.

Arnold L. Gordon

Lamont-Doherty Earth Observatory,

Palisades, New York 10964-8000, USA

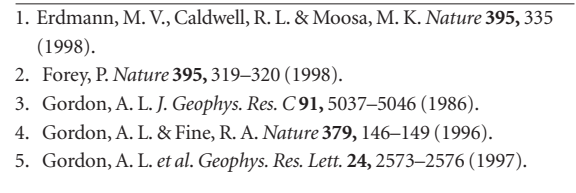

\section{Launch editor}

Sir - Robert Muir-Wood's highly readable review of Annals of the Former World by John McPhee (Nature 394, 845-846; 1998) includes an error about one of McPhee's geological guides: Eldridge Moores was indeed a powerful force in shaping the Geological Society of America's journal Geology, but he did not found it.

Geology was launched by edict of the society's council in 1973 and was shepherded by Bennie Troxel, then the society's science editor. Henry Spall (of the US Geological Survey) was appointed Geology editor and guided the journal through its early years. Moores, as editor from 1982 to 1988, applied his considerable energy to expanding Geology, both in subject matter and size. Moores is, however, erudite and charming, as Muir-Wood says. Faith Rogers Geological Society of America, 3300 Penrose Place, PO Box 9140, Boulder, Colorado 80301, USA 